\title{
A proteção constitucional do direito do consumidor na dinâmica jurisprudencial do supremo tribunal federal ${ }^{*}$
}

\section{The Constitutional Protection of Consumer Rights in the Dynamic Jurisprudence of the Brazilian Supreme Court}

\begin{abstract}
Em homenagem aos colegas professores Hector Valverde Santana, Leonardo Rosco e Bessa e Roberto Freitas Filho, representantes da nova geração que tem levado o estudo do direito do consumidor a sério.
\end{abstract}

Luís Carlos Martins Alves Jr. ${ }^{1}$

\footnotetext{
Texto construído a partir de palestra proferida na XIII Jornada Jurídica do Curso de Direito do Centro Universitário de Anápolis. Tema central: Questões atuais do Direito do Consumidor. Evento realizado no Fórum de Anápolis, entre os dias 30.5.2012 e $1^{\circ}$. 6.2012.

Recebido em outubro de 2012. Aprovado em outubro de 2012.

Bacharel em Direito, Universidade Federal do Piauí; Doutor em Direito Constitucional, Universidade Federal de Minas Gerais; Professor de Direito Constitucional, Centro Universitário de Brasília e Centro Universitário de Anápolis; Procurador da Fazenda Nacional perante o Supremo Tribunal Federal; Advogado inscrito na $\mathrm{OAB} / \mathrm{PI}$ e na $\mathrm{OAB} / \mathrm{DF}$.
}

\section{Resumo}

O presente texto visa analisar a proteção constitucional do direito do consumidor na dinâmica jurisprudencial do Supremo Tribunal Federal (STF), tendo em perspectiva os textos normativos e os precedentes judiciais do STF. A finalidade deste artigo consiste em verificar se as decisões do Tribunal estão em conformidade com os mandamentos constitucionais e se a Corte tem exercido um papel de protagonismo jurídico na defesa dos direitos fundamentais dos consumidores.

Palavras-chave: Direito Constitucional. Direito do Consumidor. Supremo Tribunal Federal. Precedentes judiciais.

\begin{abstract}
This paper aims to analyse the constitutional protection of consumer rights in the dynamic jurisprudence of the Brazilian Supreme Court (STF), taking into perspective the normative texts and judicial precedents of the STF. The purpose of this article is to verify wheter the Court's decisions are in accordance with the constitutional Law and the Court has played a leading role in the legal defense of the fundamental rights of consumers.
\end{abstract}

Keywords: Constitutional Law. Consumer Law. Brazilian Supreme Court. Judicial precedents. 


\section{Introdução}

Na Constituição brasileira o termo "consumidor" consta nos seguintes dispositivos:

\begin{abstract}
Art. $5^{\circ}$. Todos são iguais perante a lei, sem distinção de qualquer natureza, garantindo-se aos brasileiros e aos estrangeiros residentes no País a inviolabilidade do direito à vida, à liberdade, à igualdade, à segurança e à propriedade, nos termos seguintes:
\end{abstract}

XXXII: o Estado promoverá, na forma da lei, a defesa do consumidor;

Art. 170: A ordem econômica, fundada na valorização do trabalho humano e na livre iniciativa, tem por fim assegurar a todos existência digna, conforme os ditames da justiça social, observados os seguintes princípios:...

$\mathrm{V}$ - defesa do consumidor;

Art. 48, ADCT: O Congresso Nacional, dentro de cento e vinte dias da promulgação da Constituição, elaborará código de defesa do consumidor.

Art. 24. Compete à União, aos Estados e ao Distrito Federal legislar concorrentemente sobre:

VIII - responsabilidade por dano ao meio ambiente, ao consumidor, a bens e direitos de valor artístico, estético, histórico, turístico e paisagístico;

1.5. Art. $150, \S 5^{\circ}$. A lei determinará medidas para que os consumidores sejam esclarecidos acerca dos impostos que incidam sobre mercadorias e serviços.

1.6 Art. 155, \$2º, VII, alíneas “a” e “b”. Em relação às operações e prestações que destinem bens e serviços a consumidor final localizado em outro Estado, adotar-se-á: a) a alíquota interestadual, quando o destinatário for contribuinte do imposto; b) a alíquota interna, quando o destinatário não for contribuinte dele.

Naquilo que nos interessa imediatamente, indagase: Qual o alcance normativo desses enunciados constitucionais, na quadra paradigmática do Estado que se diz e que se quer Democrático e de Direito? Como esses dispositivos têm sido aplicados na dinâmica jurisprudencial do STF? Como conciliar a autonomia da vontade do consumidor, o seu livre-arbítrio, a sua responsabilidade com as intervenções normativas estatais, em aparente detrimento da livre iniciativa e da livre concorrência? Como conciliar a soberania nacional com os compromissos internacionais, e as autonomias constitucionais dos Estados e dos Municípios?

As respostas a essas indagações pressupõem uma análise do sistema jurídico como um todo, pois, como tem ensinado Eros Roberto Grau, ${ }^{2}$ não se interpreta o direito em tiras, mas em sua totalidade. Também visitaremos as principais decisões da Corte, tendo como parâmetro normativo a defesa do consumidor.

\section{0 paradigma interpretativo da defesa do consumidor}

Pois bem, como se vê, a defesa do consumidor foi alçada a norma constitucional e em 11 de setembro de 1990 foi promulgada a Lei no 8.078 , também conhecida como "Código de Defesa do Consumidor".

Como sabemos, o Estado Democrático de Direito é síntese e superação do Estado Liberal omisso ante as questões sociais e do Estado Social interventor nas relações econômicas. É o paradigma que pretende conciliar o liberal individualismo com a justiça social igualitária.

Nesse domínio, as relações de consumo se apresentam como campos delicados de intervenção normativa estatal. Sucede, no entanto, que o texto constitucional enuncia a necessidade da defesa do consumidor, pois parte da premissa que no desequilíbrio das relações sociais o lado mais fraco é o do consumidor. Ou seja, nas relações de consumo, a Constituição fez uma opção normativa preferencial pelos consumidores.

Consequências práticas dessa opção normativa: uma jurisprudência que efetivamente tem sido favorável ao consumidor nas controvérsias judiciais. Mas essa proteção judicial deve ser vista com cautela, sob pena de adotarmos uma visão "maternalista" do direito, no sentido de tratarmos os consumidores como verdadeiros incapazes e irresponsáveis ante as consequências de seus atos e escolhas. Nessa aludida perspectiva "maternalista", os consumidores teriam os seus atos e escolhas infelizes, mesmo que conscientes, eternamente justificados e perdoados por um sistema jurídico excessivamente protetivo.

A proteção constitucional, resguardada pela atuação judicial, deve ser para o consumidor que age de boafé em face do fornecedor ou prestador que age de má-fé. Ou seja, o Estado deve proteger a boa-fé ante a má-fé, de sorte que o consumidor de má-fé não pode se beneficiar

2 GRAU, Eros Roberto. Ensaio e discurso sobre a interpretação/
aplicação do direito. 2. ed. São Paulo: Malheiros, 2006. p. 44. 
em face de fornecedor ou prestador que age de boa-fé. É velho, porém, atual, o brocardo segundo o qual "ninguém pode se aproveitar de sua própria torpeza".

Nessa linha, a parte complexa na solução das controvérsias consumeristas consiste em descobrir se alguma das partes agiu de má-fé, ou se houve boa-fé por parte do consumidor. Chamarei de boa-fé a sinceridade de propósitos. Age de má-fé a ausência dessa sinceridade de propósitos, bem como a omissão de informações relevantes acerca de suas reais intenções. Uma relação de consumo deve ser uma relação de propósitos sinceros que não visam a prejudicar a outra parte.

No direito do consumidor não deve haver ganhadores e perdedores, mas apenas ganhadores, pois é a regulação de mútuos e recíprocos interesses. Alguém quer vender um produto (ou serviço) ou fornecer um produto (ou serviço) para outrem que deseja esse produto (ou serviço) prestado. Cuide-se que há relações sinceras nas quais o objetivo é a vitória sobre o outro, como sucede nas relações esportivas, por exemplo, uma partida de tênis.

Com efeito, o adversário sabe que o outro deseja ganhar, obter a vitória. Mas essa vitória deve ser obtida dentro das regras do jogo. De sorte que, perder, dentro das regras do jogo, é um resultado justo. No jogo, dentro das suas regras, é possível induzir o adversário em erro, iludi-lo, enganá-lo, inclusive "driblá-lo". Já nas relações de consumo não é possível "iludir", "enganar", "driblar", induzir em erro. As partes devem agir com boa-fé, com sinceridade de propósitos e devem informar, de modo recíproco, as suas verdadeiras intenções. A parte que faltar com a boa-fé ou que agir de má-fé não merece a proteção normativa do sistema jurídico.

Fincados esses alicerces, passo a analisar como o Supremo Tribunal Federal tem decidido as questões consumeristas que lhe são submetidas.

\section{Os precedentes judiciais do STF}

De início, antecipo que o STF tem uma jurisprudência defensiva no conhecimento das questões de direito do consumidor. A espantosa maioria das decisões do Tribunal é no sentido de que as controvérsias consumeristas têm caráter de conflito legal, sem alcançar violação constitucional direta.
Essa orientação jurisprudencial é facilmente comprovada pelas decisões que apreciaram a preliminar de reconhecimento de repercussão geral sobre questões que tinham o direito do consumidor como parâmetro normativo: RE 667.958, ${ }^{3}$ ARE 643.085, ${ }^{4}$ ARE $640.713,{ }^{5}$ ARE

${ }^{3}$ BRASIL. Supremo Tribunal Federal. Recurso Extraordinário. RE n. 667.958.. Recurso Extraordinário. 2. Análise da possibilidade de os entes federativos, empresas e entidades públicas ou privadas entregarem diretamente suas guias ou boletos de cobranças aos contribuintes ou consumidores 3 . Recurso Extraordinário em que a Empresa Brasileira de Correios e Telégrafos sustenta violação ao artigo $21, \mathrm{X}$, da Constituição Federal, segundo o qual compete à União manter o serviço postal e o correio aéreo nacional. 4. Razões recursais que também sustentam ofensa aos arts. 170 e 175 da CF. 5. Tema que diz respeito à organização político-administrativa do Estado, alcançando, portanto, relevância econômica, política e jurídica, que ultrapassa os interesses subjetivos da causa. 6. Repercussão Geral reconhecida. Plenário. Relator: Ministro Gilmar Mendes. Brasília, 8 de março de 2012. DJ. 27.3.2012.

${ }_{4}$ BRASIL. Supremo Tribunal Federal. Agravo em Recurso Extraordinário. RE n. 643.085.Recurso. Agravo convertido em Extraordinário. Inadmissibilidade deste. Exibição de documentos. Extratos bancários. Instituição financeira. Direito do consumidor. Tema infraconstitucional. Precedentes. Ausência de repercussão geral. Recurso extraordinário não conhecido. Não apresenta repercussão geral recurso extraordinário que, tendo por objeto dever de as instituições financeiras entregarem os extratos de conta poupança aos respectivos titulares, quando solicitados, versa sobre tema infraconstitucional. Plenário. Relator: Ministro Presidente. Brasília, 5 de agosto de 2011. DJ. 5.9.2011

5 BRASIL. Supremo Tribunal Federal. Agravo em Recurso Extraordinário. RE n. 640.713. Recurso. Agravo convertido em Extraordinário. Inadmissibilidade deste. Cláusulas previstas em contrato. Abusividade. Código de Defesa do Consumidor. Tema infraconstitucional. Precedentes. Ausência de repercussão geral. Recurso extraordinário não conhecido. Não apresenta repercussão geral recurso extraordinário que, tendo por objeto declaração por decisão judicial da abusividade do percentual da taxa de administração previsto em cláusula de contrato de consórcio, versa sobre tema infraconstitucional. Plenário. Relator: Ministro Presidente. Brasília, 5 de agosto de 2011. DJ. 21.9.2011. 
6 BRASIL. Supremo Tribunal Federal. Agravo em Recurso Extraordinário. RE n. 640.523. Recurso. Agravo convertido em Extraordinário. Inadmissibilidade deste. Valor das astreintes. Destinação. Fundo estadual de defesa do consumidor. Tema infraconstitucional. Precedentes. Ausência de repercussão geral. Recurso extraordinário não conhecido. Não apresenta repercussão geral recurso extraordinário que, tendo por objeto a possibilidade de se destinar parte do valor das astreintes a fundo de defesa do consumidor, versa sobre tema infraconstitucional. Plenário. Relator: Ministro Presidente Brasília, 23 de junho de 2011. DJ. 30.8.2011.

7 BRASIL. Supremo Tribunal Federal. Agravo em Recurso Extraordinário. RE n. 638.484. Recurso. Agravo convertido em Extraordinário. Reserva de Lei Complementar. Repasse do PIS e da COFINS. Faturas telefônicas. Consumidor. Relevância do tema. Repercussão geral reconhecida. Apresenta repercussão geral recurso extraordinário que verse sobre necessidade de Lei Complementar para autorizar o repasse do PIS e da COFINS ao consumidor, em faturas telefônicas. Plenário. Relator Ministro: Presidente. Brasília, 9, de junho de 2011. DJ. 30.8.2011.

8 BRASIL. Supremo Tribunal Federal. Agravo em Recurso Extraordinário. RE n. 640.525. Recurso. Agravo convertido em Extraordinário. Inadmissibilidade deste. Responsabilidade civil. Dano material. Relações contratuais e extracontratuais. Tema infraconstitucional. Precedentes. Ausência de repercussão geral. Recurso extraordinário não conhecido. Não apresenta repercussão geral recurso extraordinário que, tendo por objeto a responsabilidade de instituição financeira por dano material causado a consumidor, versa sobre tema infraconstitucional. Plenário. Relator: Ministro Presidente. Brasília, 9, de junho, 2011..DJ. 30.8.2011

9 BRASIL. Supremo Tribunal Federal. Agravo de Instrumento. AI n. 839.695. Recurso. Agravo de instrumento convertido em Extraordinário. Inadmissibilidade deste. Quantum indenizatório. Danos morais e materiais. Concessionária de serviço público. Consumidor. Tema infraconstitucional. Precedentes. Ausência de repercussão geral. Recurso extraordinário não conhecido. Não apresenta repercussão geral recurso extraordinário que, tendo por objeto o quantum indenizatório de condenação por danos morais e materiais decorrentes da relação entre concessionária de serviço público e consumidor, versa sobre tema infraconstitucional. Plenário. Relator Ministro Presidente Brasília, 9, de junho de 2011. DJ. 31.8.2011

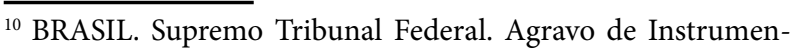
to. AI n. 844.474. Plenário. Recurso. Agravo de instrumento convertido em Extraordinário. Inadmissibilidade deste. Contratos bancários. Art. $1^{\circ}$ da Lei de Usura. Aplicação. Taxa de juros. Limite de $12 \%$ ao ano. Tema infraconstitucional. Precedentes. Ausência de repercussão geral. Recurso extraordinário não conhecido. Não apresenta repercussão geral recurso extraordinário que, tendo por objeto a aplicação, aos contratos bancários, do art. $1^{\circ}$ da Lei de Usura, que limita a taxa de juros a $12 \%$ ao ano, versa sobre tema infraconstitucional. Relator Ministro Presidente. Brasília, 9 de junho de 2011. DJ. 31.8.2011.

${ }^{11}$ BRASIL. Supremo Tribunal Federal. Agravo de Instrumento. AI $n$. 844.777. Recurso. Agravo de instrumento convertido em Extraordinário. Inadmissibilidade deste. Obrigações contratuais. Concessionária de serviço público. Área de risco. Integridade física dos funcionários. Tema infraconstitucional. Precedentes. Ausência de repercussão geral. Recurso extraordinário não conhecido. Não apresenta repercussão geral recurso extraordinário que, tendo por objeto o dever de cumprimento das obrigações contratuais, por concessionária de serviço público, em área de risco à integridade física de seus funcionários, versa sobre tema infraconstitucional. Relator: Ministro Presidente Brasília, 9, de junho de 2011. DJ. 31.8.2011

${ }^{12}$ BRASIL. Supremo Tribunal Federal. Recurso Extraordinário. $R E n$. 611.639. Veículos automotores - gravame - obrigatoriedade do registro em cartório de títulos e documentos - inconstitucionalidade do artigo 1.361, $\$ 1^{\circ}$, do código civil declarada na origem. Possui repercussão geral a controvérsia sobre a constitucionalidade do artigo 1.361, $\$ 1^{\circ}$, do Código Civil no tocante à obrigatoriedade do registro, no cartório de títulos e documentos, do contrato de alienação fiduciária de veículos automotores, mesmo com a anotação no órgão de licenciamento. Plenário. Relator: Ministro Marco Aurélio. Brasília, 9 de dezembro de 2010. DJ. 31.3.2011.

${ }^{13}$ BRASIL. Supremo Tribunal Federal. Agravo de Instrumento. AI n. 804.209: Juros. Limitação em $12 \%$ ao ano. Contratos celebrados após o advento da Emenda Constitucional n. 40/2003. Legislação Infraconstitucional. Inexistência de repercussão geral. Plenário. Relator: Ministro Gilmar Mendes. Brasília: 16, de setembro de 2010. DJ. 14.10.2010. 
$751.521,{ }^{14}$ AI $765.567,{ }^{15}$ AI $754.745,{ }^{16}$ RE $591.797,{ }^{17}$ AI
$762.184,{ }^{18} \mathrm{RE} 579.073,{ }^{19} \mathrm{RE} 576.189,{ }^{20} \mathrm{RE} 565.138^{21}$ e RE $641.005 .^{22}$

Ou seja, a Corte, na maioria das vezes, não enfrenta as causas relativas ao Direito do Consumidor, pelo fundamento de se tratar de matéria infraconstitucional. Sucede que o Direito do Consumidor é direito fundamental, por essa expressa dicção constitucional. Se o STF é uma "Corte Judicial de Direitos Fundamentais", como tem reverberado, em princípio, as questões de direito do consumidor deveriam receber outro tratamento judicial.

Mas não é o que acontece. A rigor, neste país, o grande tribunal das causas dos consumidores é o Supe-

${ }_{18}$ BRASIL. Supremo Tribunal Federal. Agravo de Instrumento. AI n. 762.184. Recurso. Extraordinário. Extravio de bagagem. Limitação de danos materiais e morais. Convenção de Varsóvia. Código de Defesa do Consumidor. Princípio constitucional da indenizabilidade irrestrita. Norma prevalecente. Relevância da questão. Repercussão geral reconhecida. Apresenta repercussão geral o recurso extraordinário que verse sobre a possibilidade de limitação, com fundamento na Convenção de Varsóvia, das indenizações de danos morais e materiais, decorrentes de extravio de bagagem. Plenário. Relator: Ministro Cezar Peluso. Brasília, 22, de outubro de 2009. DJ. 17.12.2009

${ }^{19}$ BRASIL. Supremo Tribunal Federal. Recurso Extraordinário. $R E$ n. 579.073. Recurso. Extraordinário. Incognoscibilidade. Sistema financeiro da habitação. Contrato de mútuo. Saldo devedor. Critério de reajuste. Questão infraconstitucional. Precedentes. Ausência de repercussão geral. Recurso extraordinário não conhecido. Não apresenta repercussão geral o recurso extraordinário que, tendo por objeto questão relativa ao critério de reajuste de saldo devedor de contrato de mútuo firmado no âmbito do sistema financeiro da habitação, versa sobre matéria infraconstitucional. Plenário. Relator: Ministro Cezar Peluso. Brasília, 17. De setembro de 2009. DJ. 12.11.2009

${ }^{20}$ BRASIL. Supremo Tribunal Federal. Recurso Extraordinário. $R E n$. 576.189. Da constitucionalidade dos encargos previstos na lei 10.438/2002. natureza jurídica. tarifa ou tributo. Relevância econômica e jurídica. Quantidade extraordinária de recursos. número elevado de processos judiciais. Existência de repercussão geral. Plenário. Relator: Ministro Ricardo Lewandowski. Brasília, 20 de março de.2008.

${ }^{21}$ BRASIL. Supremo Tribunal Federal. Recurso Extraordinário. $R E$ n. 565.138. Código de Defesa do Consumidor. Danos materiais e morais. Recurso Extraordinário interposto pela Confederação Brasileira de Futebol - CBF. Ausência de repercussão geral. Plenário. Relator: Ministro Menezes Direito. Brasília, 5, dezembro de 2007. DJ. 6.12.2007.

${ }^{22}$ BRASIL. Supremo Tribunal Federal. Recurso Extraordinário. $R E$ n. 641.005. Ementa: Direito constitucional e consumerista. Autonomia universitária. Prestação de serviços educacionais por instituição privada. Relação de consumo. sujeição ao princípio da defesa do consumidor. Pagamento de valor a título de semestralidade independente da carga horária e do número de disciplinas. Plenário. Relator: Ministro Luiz Fux. Brasília, 24 de maio de 2012. DJe. 22.6.2012 
rior Tribunal de Justiça. Nada obstante essa jurisprudência restritiva, o STF tem importantes decisões nessa matéria, que merecem nossa atenção. Passo ao exame delas.

Cuide-se que há duas Súmulas da Corte que tocam a matéria do consumidor: a Súmula no 643 e a Súmula Vinculante ${ }^{\circ} 27$.

\author{
A Súmula 643 tem o seguinte enunciado: \\ O Ministério Público tem legitimidade para \\ promover ação civil pública cujo fundamento \\ seja a ilegalidade de reajuste de mensalidades \\ escolares.
}

SV 27 tem o seguinte teor normativo:

Compete à justiça estadual julgar causas entre consumidor e concessionária de serviço público de telefonia, quando a ANATEL não seja litisconsorte passiva necessária, assistente, nem opoente.

Tramita na Corte um feito relevante, tanto para o Direito do Consumidor quanto para o Direito Internacional. Trata-se do reconhecimento de repercussão geral, nos autos do AI 762.18, ${ }^{23}$ relatoria Ministro Cezar Peluso, que apreciará o tema do Direito do Consumidor e a Convenção de Varsóvia.

A questão discute sobre a possibilidade de limitação, com fundamento na Convenção de Varsóvia (uma convenção internacional subscrita pela República brasileira), das indenizações de danos morais e materiais, decorrentes de extravio de bagagem. O Tribunal tem jurisprudência vacilante sobre esse tema.

${ }^{23}$ BRASIL. Supremo Tribunal Federal. Agravo de Instrumento. AI n. 762.184. Questão de Ordem. Recurso. Extraordinário. Extravio de bagagem. Limitação de danos materiais e morais. Convenção de Varsóvia. Código de Defesa do Consumidor. Princípio constitucional da indenizabilidade irrestrita. Norma prevalecente. Relevância da questão. Repercussão geral reconhecida. Apresenta repercussão geral o recurso extraordinário que verse sobre a possibilidade de limitação, com fundamento na Convenção de Varsóvia, das indenizações de danos morais e materiais, decorrentes de extravio de bagagem. Questão de Ordem, Relator Ministro: Cezar Peluso. Brasília, 22 de dezembro de 2009. DJ. 17.12.2009
Com efeito, no julgamento do RE 297.901, ${ }^{24}$ a $2^{\text {a }}$ Turma do Tribunal decidiu, com apoio no precedente estabelecido no RE $214.349,{ }^{25}$ da $1^{\text {a }}$ Turma, que no caso específico de transporte internacional aéreo, com espeque no art. 178, CF, prevalece a Convenção de Varsóvia. Todavia, no RE $351.750,{ }^{26}$ a $1^{\text {a }}$ Turma, revendo seu entendimento, decidiu que o princípio da defesa do consumidor se aplica a todo capítulo constitucional da atividade econômica e que as normas constantes do Código Brasileiro da Aeronáutica e da Convenção de Varsóvia devem ser afastadas quando implicarem retrocesso social ou vi-

${ }^{24}$ BRASIL. Supremo Tribunal Federal. Recurso Extraordinário. RE n. 297.901.. Prazo prescricional. Convenção de varsóvia e código de defesa do consumidor. $1 . \mathrm{O}$ art. $5^{\circ}, \$ 2^{\circ}$, da Constituição Federal se refere a tratados internacionais relativos a direitos e garantias fundamentais, matéria não objeto da Convenção de Varsóvia, que trata da limitação da responsabilidade civil do transportador aéreo internacional (RE 214.349, Rel. Min. Moreira Alves, DJ 11.6.99). 2. Embora válida a norma do Código de Defesa do Consumidor quanto aos consumidores em geral, no caso específico de contrato de transporte internacional aéreo, com base no art. 178 da Constituição Federal de 1988, prevalece a Convenção de Varsóvia, que determina prazo prescricional de dois anos. 3. Recurso provido. Segunda Turma. Relatora: Ministra Ellen Gracie. Brasília, 7, de março de 2006. DJ. 31.3.2006

${ }^{25}$ BRASIL. Supremo Tribunal Federal. Recurso Extraordinário. RE $n$. 214.349. Recurso extraordinário. Responsabilidade civil. Transporte aéreo internacional. - As questões relativas aos artigos 5, II, 93, IX, e 178 da Constituição Federal não foram ventiladas na decisão recorrida, nem foram objeto de embargos de declaração, motivo por que lhes falta o indispensável prequestionamento (súmulas 282 e 356 ). Por outro lado, no tocante à alegação de ofensa ao artigo $5^{\circ}, \S 2^{\circ}$, da Constituição, ela não ocorre, porquanto esse dispositivo se refere a tratados internacionais relativos a direitos e garantias fundamentais, o que não é matéria objeto da Convenção de Varsóvia e do Protocolo de Haia no tocante à limitação da responsabilidade civil do transportador aéreo internacional. Recurso extraordinário não conhecido. Primeira Turma. Relator: Ministro Moreira Alves. Brasília, 13 de abril de 1999. DJ. 11.6.1999.

${ }^{26}$ BRASIL. Supremo Tribunal Federal. Recurso Extraordinário. $R E$ n. 351.750. Recurso extraordinário. Danos morais decorrentes de atraso ocorrido em voo internacionaL. Aplicação do código de defesa do consumidor. Matéria infraconstitucional. Não conhecimento. 1. O princípio da defesa do consumidor se aplica a todo o capítulo constitucional da atividade econômica. 2. Afastam-se as normas especiais do Código Brasileiro da Aeronáutica e da Convenção de Varsóvia quando implicarem retrocesso social ou vilipêndio aos direitos assegurados pelo Código de Defesa do Consumidor. 3. Não cabe discutir, na instância extraordinária, sobre a correta aplicação do Código de Defesa do Consumidor ou sobre a incidência, no caso concreto, de específicas normas de consumo veiculadas em legislação especial sobre o transporte aéreo internacional. Ofensa indireta à Constituição de República. 4. Recurso não conhecido. Primeira Turma. Relator: Ministro Ayres Britto. Brasília, 17, de março de 2009. DJ. 24.9.2009. 
lipêndio aos direitos assegurados pelo Código de Defesa do Consumidor.

O voto-vencedor, capitaneado pelo Ministro Ayres Britto, ${ }^{27}$ atual presidente da Corte, se fiou na tese segundo a qual as normas constitucionais sobre o direito do consumidor densificam o princípio constitucional da dignidade da pessoa humana. Nessa perspectiva, segundo o Ministro Ayres Britto, as normas relativas ao direito do consumidor, por serem normas de direitos fundamentais, não poderiam sofrer retrocesso que lhes enfraquecessem.

Desse entendimento divergiu o Ministro Eros Grau. Segundo ele, ${ }^{28}$ no caso específico de indenização de transporte aéreo internacional, deve prevalecer a norma específica constante nos acordos internacionais assumidos pela República brasileira.

Nada obstante a divergência do Ministro Eros Grau, os demais ministros da Turma acompanharam o voto vencedor do Ministro Ayres Britto.

A empresa aérea recorrente (VARIG S/A) interpôs o recurso de embargos divergentes, de sorte que esse aludido feito ainda não transitou em julgado. Como assinalado, o tema teve sua repercussão geral reconhecida e será julgado definitivamente pelo soberano plenário da Corte. É uma questão delicada.

De um lado, o direito fundamental do consumidor de receber uma justa e adequada indenização, se houver a aplicação do Código de Defesa do Consumidor.

De outro lado, a incidência de norma internacional vigente, que estaria sendo afastada pelo STF brasileiro.

Eis o aspecto complicador: ou o Brasil, via STF, escolhe aplicar a legislação nacional, em homenagem ao direito fundamental do consumidor ou escolhe aplicar a legislação internacional, em homenagem à boa-fé e à segurança jurídica nas relações internacionais.

Pessoalmente, entendo que "tratado assinado é tratado cumprido”. Ou seja, não é lícito a nenhum Estado soberano, sob nenhum pretexto, deixar de cumprir as normas internacionais que soberanamente resolveu se submeter. Defendo também que a soberania nacional

\footnotetext{
${ }^{27}$ BRITTO, Ayres. Brasil. Supremo Tribunal Federal. Recurso Extraordinário. RE n. 351.750. Brasília, DF, 2009. p. 11121117.

${ }^{28}$ GRAU, Eros. Brasil. Supremo Tribunal Federal. Recurso Extraordinário n. 351.750. Brasília, DF, 2009. p. 1118-1120.
}

está em assinar ou deixar de assinar um tratado ou acordo internacional. Está em denunciar esse tratado internacional, mas nunca em descumpri-lo.

Um Estado que deixa de honrar os seus compromissos internacionais não é um Estado digno nem decente, e não merece o crédito nem a confiança da comunidade internacional. Estados que invocam suas leis internas para descumprirem seus compromissos internacionais assumidos conscientemente são Estados “indecentes”, governados por "moleques". Se o Estado não quer cumprir, que denuncie o tratado e assuma as consequências decorrentes desses atos.

Se fosse fazer um exercício de prognose judicial, diria que o Tribunal decidirá pela aplicação da legislação nacional em desfavor da legislação internacional. A bem da verdade, recorde-se que o Tribunal tem palmilhado um entendimento no sentido da supralegalidade normativa dos tratados internacionais. ${ }^{29}$

Mas, ainda assim, entendo que o STF optará em favor da lei nacional. Provavelmente o Tribunal justificará esse entendimento sob o argumento de que as normas jurídicas internacionais não podem reduzir a potência normativa das normas jurídicas de direitos fundamentais, instalando o direito do consumidor como "cláusula pétrea".

${ }^{29}$ BRASIL. Supremo Tribunal Federal. Informativo n. 531. Em conclusão de julgamento, o Tribunal concedeu habeas corpus em que se questionava a legitimidade da ordem de prisão, por 60 dias, decretada em desfavor do paciente que, intimado a entregar o bem do qual depositário, não adimplira a obrigação contratual - v. Informativos 471, 477 e 498. Entendeu-se que a circunstância de o Brasil haver subscrito o Pacto de São José da Costa Rica, que restringe a prisão civil por dívida ao descumprimento inescusável de prestação alimentícia (art. $7^{\circ}$, 7), conduz à inexistência de balizas visando à eficácia do que previsto no art. $5^{\circ}$, LXVII, da CF ("não haverá prisão civil por dívida, salvo a do responsável pelo inadimplemento voluntário e inescusável de obrigação alimentícia e a do depositário infiel;"). Concluiu-se, assim, que, com a introdução do aludido Pacto no ordenamento jurídico nacional, restaram derrogadas as normas estritamente legais definidoras da custódia do depositário infiel. Prevaleceu, no julgamento, por fim, a tese do status de supralegalidade da referida Convenção, inicialmente defendida pelo Min. Gilmar Mendes no julgamento do RE 466343/SP, abaixo relatado. Vencidos, no ponto, os Ministros Celso de Mello, Cezar Peluso, Ellen Gracie e Eros Grau, que a ela davam a qualificação constitucional, perfilhando o entendimento expendido pelo primeiro no voto que proferira nesse recurso. O Min. Marco Aurélio, relativamente a essa questão, se absteve de pronunciamento. HC 87585/TO. Relator: Min. Marco Aurélio. Brasília, 3 de dezembro de 2008. 
Tenha-se que a proteção constitucional do consumidor se revela muito mais um direito social coletivo do que um direito liberal individual. Em sendo um direito social coletivo, em vez de um direito liberal individual, não estaria o direito do consumidor albergado pela superproteção das "cláusulas pétreas", que se refere unicamente aos direitos e garantias fundamentais individuais, mas não a todo e qualquer direito fundamental, como soe acontecer com os direitos fundamentais coletivos e direitos fundamentais sociais. ${ }^{30}$ Mas, como já dito, creio que o Tribunal optará pela legislação nacional em desfavor da legislação internacional. Aguardemos.

Passo ao exame de outro tema apreciado pelo STF. O Tribunal na ADIN 2.591 decidiu que o CDC aplica-se

${ }^{30}$ Em outra oportunidade escrevi: "A partir da própria Constituição, podemos classificar os direitos fundamentais nas seguintes categorias: direitos individuais, direitos coletivos, direitos liberais, direitos sociais e direitos democráticos. Os direitos individuais são aqueles que a pessoa pode exercer autonomamente, independentemente do concurso de outras pessoas, é um direito seu (singelo exemplo: liberdade de crença ou descrença). Os direitos coletivos são aqueles que somente podem ser exercidos por pelo menos mais de uma pessoa, por um grupo coletivo, é indispensável o concurso de outra pessoa (singelo exemplo: liberdade associativa). Os direitos liberais são aqueles que reduzem ou excluem a intervenção do Poder Público na vida das pessoas, é um direito de negação à intrusão do Estado na vida dos indivíduos (singelo exemplo: intimidade). Direitos sociais são aqueles que dependem da atuação do Poder Público ou que exigem prestações positivas do Estado para a efetivação e exercício desses direitos (singelo exemplo: educação pública)." ALVES Júnior, Luís Carlos Martins. Direitos constitucionais fundamentais. Belo Horizonte: Mandamentos, 2010. p. 59. às instituições financeiras e companhias seguradoras. ${ }^{31}$

${ }^{31}$ BRASIL. Supremo Tribunal Federal. Ação Direta de Inconstitucionalidade. $A D I$ n. 2.591. Código de defesa do consumidor. art. 5, XXXII, da CB/88. ART. 170, V, da CB/88. Instituições financeiras. Sujeição delas ao código de defesa do consumidor, excluídas de sua abrangência a definição do custo das operações ativas e a remuneração das operações passivas praticadas na exploração da intermediação de dinheiro na economia [ART. $3^{\circ}, \$ 2^{\circ}$, DO CDC]. Moeda e taxa de juros. Dever-poder do banco central do Brasil. Sujeição ao código civil. 1. As instituições financeiras estão, todas elas, alcançadas pela incidência das normas veiculadas pelo Código de Defesa do Consumidor. 2. "Consumidor", para os efeitos do Código de Defesa do Consumidor, é toda pessoa física ou jurídica que utiliza, como destinatário final, atividade bancária, financeira e de crédito. 3 . O preceito veiculado pelo art. $3^{\circ}, \S 2^{\circ}$, do Código de Defesa do Consumidor deve ser interpretado em coerência com a Constituição, o que importa em que o custo das operações ativas e a remuneração das operações passivas praticadas por instituições financeiras na exploração da intermediação de dinheiro na economia estejam excluídas da sua abrangência. 4. Ao Conselho Monetário Nacional incumbe a fixação, desde a perspectiva macroeconômica, da taxa base de juros praticável no mercado financeiro. 5. O Banco Central do Brasil está vinculado pelo dever-poder de fiscalizar as instituições financeiras, em especial na estipulação contratual das taxas de juros por elas praticadas no desempenho da intermediação de dinheiro na economia. 6. Ação direta julgada improcedente, afastando-se a exegese que submete às normas do Código de Defesa do Consumidor [Lei n. 8.078/90] a definição do custo das operações ativas e da remuneração das operações passivas praticadas por instituições financeiras no desempenho da intermediação de dinheiro na economia, sem prejuízo do controle, pelo Banco Central do Brasil, e do controle e revisão, pelo Poder Judiciário, nos termos do disposto no Código Civil, em cada caso, de eventual abusividade, onerosidade excessiva ou outras distorções na composição contratual da taxa de juros. ART. 192, DA CB/88. NORMA-OBJETIVO. EXIGÊNCIA DE LEI COMPLEMENTAR EXCLUSIVAMENTE PARA A REGULAMENTAÇÃO DO SISTEMA FINANCEIRO. 7. O preceito veiculado pelo art. 192 da Constituição do Brasil consubstancia norma-objetivo que estabelece os fins a serem perseguidos pelo sistema financeiro nacional, a promoção do desenvolvimento equilibrado do País e a realização dos interesses da coletividade. 8 . A exigência de lei complementar veiculada pelo art. 192 da Constituição abrange exclusivamente a regulamentação da estrutura do sistema financeiro. CONSELHO MONETÁRIO NACIONAL. ART. $4^{\circ}$, VIII, DA LEI N. 4.595/64. CAPACIDADE NORMATIVA ATINENTE À CONSTITUIÇÃO, FUNCIONAMENTO E FISCALIZAÇÃO DAS INSTITUIÇÕES FINANCEIRAS. ILEGALIDADE DE RESOLUÇÕES QUE EXCEDEM ESSA MATÉRIA. 9. O Conselho Monetário Nacional é titular de capacidade normativa --- a chamada capacidade normativa de conjuntura --- no exercício da qual lhe incumbe regular, além da constituição e fiscalização, o funcionamento das instituições financeiras, isto é, o desempenho de suas atividades no plano do sistema financeiro. 10. Tudo o quanto exceda esse desempenho não pode ser objeto de regulação por ato normativo produzido pelo Conselho Monetário Nacional. 11. A produção de atos normativos pelo Conselho Monetário Nacional, quando não respeitem ao funcionamento das instituições financeiras, é abusiva, consubstanciando afronta à legalidade. Plenário. Relator: Ministro Eros Grau. Brasília, 7 de junho de 2006. DJ. 29.9.2006. 
Nesse aludido julgamento a Corte enfrentou a forte pressão das instituições financeiras que postulavam uma interpretação conforme a Constituição no sentido de que os clientes das instituições financeiras e das companhias seguradoras não poderiam ser confundidos com os consumidores de outras empresas, pois haveria peculiaridades das relações financeiras que a distinguiam das outras relações econômicas.

Sem embargo da forte pressão exercida pelas instituições financeiras, o Tribunal, na linha do voto preconizado pelo Ministro Eros Grau, decidiu que o CDC aplica-se integralmente às relações financeiras e securitárias, estando o $\$ 2^{\circ}$ do art. $3^{\circ}$ do Código de Defesa do Consumidor indene de vícios.

Outro julgamento interessante ocorreu nos autos da $\mathrm{ADC}^{32}$ no qual o Tribunal reconheceu a validade constitucional das medidas governamentais à época do racionamento de energia elétrica, especificamente as sobretarifas para os consumidores que excederem os limites de consumo. A Corte, em homenagem à solidariedade social, admitiu o afastamento das normas consumeristas

${ }^{32}$ BRASIL. Supremo Tribunal Federal. Ação Declaratória de Constitucionalidade n. 9. Ação declaratória de constitucionalidade. Medida provisória $\mathrm{n}^{\circ} 2.152-2$, de $1^{\circ}$ de junho de 2001, e posteriores reedições. Artigos 14 A 18. Gestão da crise de energia elétrica. Fixação de metas de consumo e de um regime especial de tarifação. 1 . O valor arrecadado como tarifa especial ou sobretarifa imposta ao consumo de energia elétrica acima das metas estabelecidas pela Medida Provisória em exame será utilizado para custear despesas adicionais, decorrentes da implementação do próprio plano de racionamento, além de beneficiar os consumidores mais poupadores, que serão merecedores de bônus. Este acréscimo não descaracteriza a tarifa como tal, tratando-se de um mecanismo que permite a continuidade da prestação do serviço, com a captação de recursos que têm como destinatários os fornecedores/ concessionários do serviço. Implementação, em momento de escassez da oferta de serviço, de política tarifária, por meio de regras com força de lei, conforme previsto no artigo 175, III da Constituição Federal. 2. Atendimento aos princípios da proporcionalidade e da razoabilidade, tendo em vista a preocupação com os direitos dos consumidores em geral, na adoção de medidas que permitam que todos continuem a utilizar, moderadamente, de uma energia que se apresenta incontestavelmente escassa. 3. Reconhecimento da necessidade de imposição de medidas como a suspensão do fornecimento de energia elétrica aos consumidores que se mostrarem insensíveis à necessidade do exercício da solidariedade social mínima, assegurada a notificação prévia (art. 14, $\$ 4^{\circ}$, II) e a apreciação de casos excepcionais (art. 15, $\left.\$ 5^{\circ}\right) .4$. Ação declaratória de constitucionalidade cujo pedido se julga procedente. Plenário. Relatora: Ministra Ellen Gracie. Plenário. Brasília, 13 de dezembro de 2001. DJ. 23.4.2004. em favor da continuidade da prestação do serviço de fornecimento de energia elétrica para todos, restringindo, via racionamento, a utilização de medidas sancionatórias contra os consumidores recalcitrantes.

Nos julgamentos das ADINs $1.980^{33}$ e $2.832,{ }^{34} \mathrm{o}$ STF decidiu favoravelmente às legislações paranaenses que asseguram ao consumidor o direito de obter informações sobre a natureza, a procedência e a qualidade dos produtos comercializados no Estado do Paraná, e que essas legislações não usurpavam a competência normativa da União Federal, haja vista a competência concorrente sobre o Direito do Consumidor. No entanto, no julga-

${ }^{33}$ BRASIL. Supremo Tribunal Federal. Ação Direta de Inconstitucionalidade. ADI n. 1.980. Inconstitucionalidade. Ação direta. Lei no 12.420/99, do Estado do Paraná. Consumo. Comercialização de combustíveis no Estado. Consumidor. Direito de obter informações sobre a natureza, procedência e qualidade dos produtos. Proibição de revenda em postos com marca e identificação visual de outra distribuidora. Prevenção de publicidade enganosa. Sanções administrativas. Admissibilidade. Inexistência de ofensa aos arts. 22, incs. I, IV e XII, 170 , incs. IV, 177, $\$ \$ 1^{\circ}$ e $2^{\circ}$, e 238 , todos da CF. Ação julgada improcedente. Aplicação dos arts. 24 , incs. V e VIII, cc. $\$ 2^{\circ}$, e 170, inc. V, da CF. É constitucional a Lei no 12.420 , de 13 de janeiro de 1999, do Estado do Paraná, que assegura ao consumidor o direito de obter informações sobre a natureza, procedência e qualidade de produtos combustíveis comercializados nos postos revendedores do Estado. Plenário. Relator: Ministro Cezar Peluso. Brasília, 16 de abril de 2009. DJ. 6.8.2009.

${ }^{34}$ BRASIL. Supremo Tribunal Federal. Ação Direta de Inconstitucionalidade. ADI n. 2.832. Direito constitucional e administrativo. ADI contra lei paranaense 13.519 , de 8 de abril de 2002, que estabelece obrigatoriedade de informação, conforme especifica, nos rótulos de embalagens de café comercializado no paraná. alegação de ofensa aos arts. 22, i e viii, 170 , caput, iv, e parágrafo único, e 174 da Constituição Federal. Proteção ao consumidor. Ofensa indireta. Ação julgada parcialmente procedente. I - Não há usurpação de competência da União para legislar sobre direito comercial e comércio interestadual porque o ato normativo impugnado buscou, tão-somente, assegurar a proteção ao consumidor. II - Precedente deste Tribunal (ADI 1.980, Rel. Min. Sydney Sanches) no sentido de que não invade esfera de competência da União, para legislar sobre normas gerais, lei paranaense que assegura ao consumidor o direito de obter informações sobre produtos combustíveis. III - Afronta ao texto constitucional indireta na medida em que se mostra indispensável o exame de conteúdo de outras normas infraconstitucionais, no caso, o Código do Consumidor. IV - Inocorre delegação de poder de fiscalização a particulares quando se verifica que a norma impugnada estabelece que os selos de qualidade serão emitidos por entidades vinculadas à Administração Pública estadual. V - Ação julgada parcialmente procedente apenas no ponto em que a lei impugnada estende os seus efeitos a outras unidades da Federação. Plenário. Relator: Ministro Ricardo Lewandowski. Brasília,7 de maio de.2008. DJ. 19.6.2008 
mento da ADIN 855, ${ }^{35}$ o STF declarou inconstitucional a lei paranaense que obrigava os estabelecimentos que comercializassem GLP (gás liquefeito de petróleo) a pesarem, à vista do consumidor, os botijões ou cilindros entregues ou recebidos para substituição, com abatimento proporcional do preço do produto.

Nesse aludido julgamento, o Tribunal entendeu que houve violação à competência privativa da União Federal para legislar sobre energia e petróleo, bem como violação dos princípios da proporcionalidade e da razoabilidade, por conter exigência demasiadamente onerosa para a atividade empresarial.
${ }^{35}$ BRASIL. Supremo Tribunal Federal. Ação Direta de Inconstitucionalidade. ADI $n$. 855. Ação direta de inconstitucionalidade. 2. Lei 10.248/93, do Estado do Paraná, que obriga os estabelecimentos que comercializem Gás Liquefeito de Petróleo - GLP a pesarem, à vista do consumidor, os botijões ou cilindros entregues ou recebidos para substituição, com abatimento proporcional do preço do produto ante a eventual verificação de diferença a menor entre o conteúdo e a quantidade líquida especificada no recipiente. 3. Inconstitucionalidade formal, por ofensa à competência privativa da União para legislar sobre o tema (CF/88, arts. 22, IV, 238). 4. Violação ao princípio da proporcionalidade e razoabilidade das leis restritivas de direitos. 5. Ação julgada procedente. Plenário. Relator: Ministro Octávio Gallotti. Brasília, 6 de março de 2008. DJ. 27.3.2009.
Pois bem, no julgamento da ADIN $2.359,{ }^{36}$ o Tribunal julgou improcedente a ação e manteve a vigência da legislação capixaba impugnada que cuidava da requalificação dos botijões de GLP. Entendeu o Tribunal que a lei capixaba não usurpou a competência normativa da União Federal, pois o tema versado é de competência concorrente entre os Estados e a União, bem como a citada lei dava concreção ao disposto no art. 170, V, CF, no que promovia a defesa do consumidor.

Há vários outros precedentes nos quais os direitos dos consumidores serviram como parâmetro nor-

${ }^{36}$ BRASIL. Supremo Tribunal Federal. Ação Direta de Inconstitucionalidade. ADI n. 2.359. Ação direta de inconstitucionalidade. lei n. 5.652, do estado do Espírito Santo. Comercialização de produtos por meio de vasilhames, recipientes ou embalagens reutilizáveis. gás liquefeito de petróleo engarrafado [GLP]. Diretrizes relativas à requalificação dos botijões. Alegação de violação do disposto nos artigos $5^{\circ}$, Inciso XXIX, e 22, inciso I, da Constituição do Brasil. Inocorrência. O estado-membro detém competência legislativa para dispor a respeito das matérias de produção e consumo [Artigo 24, inciso V, da Constituição do Brasil]. Defesa do consumidor [ARTIGO 170, V, da Constituição do Brasil]. 1. Não procede a alegação de violação à proteção às marcas e criações industriais. A lei impugnada não dispõe a respeito dessa matéria. 2 . O texto normativo questionado contém diretrizes relativamente ao consumo de produtos acondicionados em recipientes reutilizáveis --- matéria em relação à qual o Estado-membro detém competência legislativa [artigo 24, inciso V, da Constituição do Brasil]. 3. Quanto ao gás liquefeito de petróleo [GLP], a lei impugnada determina que o titular da marca estampada em vasilhame, embalagem ou recipiente reutilizável não obstrua a livre circulação do continente [artigo $1^{\circ}$, caput]. Estabelece que a empresa que reutilizar o vasilhame efetue sua devida identificação através de marca, logotipo, caractere ou símbolo, de forma a esclarecer o consumidor [artigo $2^{\circ}$ ]. 4 . A compra de gás da distribuidora ou de seu revendedor é operada concomitantemente à realização de uma troca, operada entre o consumidor e o vendedor de gás. Trocam-se botijões, independentemente de qual seja a marca neles forjada. Dinamismo do mercado do abastecimento de gás liquefeito de petróleo. 5. A lei hostilizada limita-se a promover a defesa do consumidor, dando concreção ao disposto no artigo 170, V, da Constituição do Brasil. O texto normativo estadual dispõe sobre matéria da competência concorrente entre a União, os Estados-membros e o Distrito Federal. 6. Ação Direta de Inconstitucionalidade julgada improcedente. Plenário. Relator: Ministro Eros Grau. Brasília, 27, de novembro de 2006. DJ. 7.12.2006 
mativo da decisão do STF: ADIN 3.322, ${ }^{37}$ ADIN 3.645, ${ }^{38}$
RE 432.789, ${ }^{39}$ RE 201.630, ${ }^{40}$ ADIN $2.435-M^{41}$ e RE $189.170 .^{42}$
${ }^{37}$ BRASIL. Supremo Tribunal Federal. Ação Direta de Inconstitucionalidade. $A D I n$. 3.322. Ação direta de inconstitucionalidade. 2. Lei Distrital n. 3.426/2004. 3. Serviço público de Telecomunicações. 4. Telefonia fixa. 5. Obrigação de discriminar informações na fatura. 6. Definição de ligação local. 7. Disposições sobre ônus da prova, termo de adequação e multa. 8 . Invasão da competência legislativa da União. 9. Violação dos artigos 22, incisos I, IV, e 175, da CF. Precedentes. 10. Ação direta de inconstitucionalidade julgada procedente. Plenário. Relator: Ministro Gilmar Mendes. Brasília, 2, de dezembro de 2010. DJ. 3.3.2011.

${ }^{38}$ BRASIL. Supremo Tribunal Federal. Ação Direta de Inconstitucionalidade. ADI n. 3.645. Ação direta de inconstitucionalidade. LEI 14.861/05, do estado do Paraná. Informação quanto à presença de organismos geneticamente modificados em alimentos e ingredientes alimentares destinados ao consumo humano e animal. Lei federal 11.105/05 e decretos 4.680/03 e 5.591/05. Competência legislativa concorrente para dispor sobre produção, consumo e proteção e defesa da saúde. art. 24, V e XII, da Constituição Federal. Estabelecimento de normas gerais pela união e competência suplementar dos estados. 1. Preliminar de ofensa reflexa afastada, uma vez que a despeito da constatação, pelo Tribunal, da existência de normas federais tratando da mesma temática, está o exame na ação adstrito à eventual e direta ofensa, pela lei atacada, das regras constitucionais de repartição da competência legislativa. Precedente: ADI 2.535-MC, Rel. Min. Sepúlveda Pertence, DJ 21.11.03. 2. Seja dispondo sobre consumo (CF, art. 24, V), seja sobre proteção e defesa da saúde (CF, art. 24, XII), busca o Diploma estadual impugnado inaugurar regulamentação paralela e explicitamente contraposta à legislação federal vigente. 3. Ocorrência de substituição - e não suplementação - das regras que cuidam das exigências, procedimentos e penalidades relativos à rotulagem informativa de produtos transgênicos por norma estadual que dispôs sobre o tema de maneira igualmente abrangente. Extrapolação, pelo legislador estadual, da autorização constitucional voltada para o preenchimento de lacunas acaso verificadas na legislação federal. Precedente: ADI 3.035, Rel. Min. Gilmar Mendes, DJ 14.10.05. 4. Declaração de inconstitucionalidade conseqüencial ou por arrastamento de decreto regulamentar superveniente em razão da relação de dependência entre sua validade e a legitimidade constitucional da lei objeto da ação. Precedentes: ADI 437-QO, Rel. Min. Celso de Mello, DJ 19.02.93 e ADI 173-MC, Rel. Min. Moreira Alves, DJ 27.04.90. 5. Ação direta cujo pedido formulado se julga procedente. Plenário. Relatora: Ministra Ellen Gracie. Brasília, 31, de maio de 2006. DJ. $1^{\circ}$. 9.2006 .
${ }^{39}$ BRASIL. Supremo Tribunal Federal. Recurso Extraordinário. RE n. 432.789. Recurso extraordinário. Constitucional. Consumidor. Instituição bancária. Atendimento ao público. Fila. Tempo de espera. Lei municipal. Norma de interesse local. Legitimidade. Lei Municipal n. 4.188/01. Banco. Atendimento ao público e tempo máximo de espera na fila. Matéria que não se confunde com a atinente às atividades-fim das instituições bancárias. Matéria de interesse local e de proteção ao consumidor. Competência legislativa do Município. Recurso extraordinário conhecido e provido. Primeira Turma. Relator: Ministro Eros Grau. Brasília, 14, de junho de 2005. DJ. 7.10.2005

${ }^{40}$ BRASIL. Supremo Tribunal Federal. Recurso Extraordinário. $R E$ n. 201.630. Serviço de fornecimento de água. Adicional de tarifa. Legitimidade. Mostra-se coerente com a jurisprudência do Supremo Tribunal o despacho agravado, ao apontar que o ajuste de carga de natureza sazonal, aplicável aos fornecimentos de água pela CAESB, criado para fins de redução de consumo, tem caráter de contraprestação de serviço e não de tributo. Precedentes: ERE 54.491, RE 85.268, RE 77.77.162 e ADC 09. Agravo regimental desprovido. Primeira Turma. Relatora: Ministra Ellen Gracie. Brasília, 11, de junho de 2002. DJ. 2.8.2002

${ }^{41}$ BRASIL. Supremo Tribunal Federal. Ação Direta de Inconstitucionalidade. ADI n. 2.435. Medida Cautelar. Ação direta de inconstitucionalidade. Lei $\mathrm{n}^{\circ} 3.542 / 01$, do Estado do Rio de Janeiro, que obrigou farmácias e drogarias a conceder descontos a idosos na compra de medicamentos. Ausência do periculum in mora, tendo em vista que a irreparabilidade dos danos decorrentes da suspensão ou não dos efeitos da lei se dá, de forma irremediável, em prejuízo dos idosos, da sua saúde e da sua própria vida. Periculum in mora inverso. Relevância, ademais, do disposto no art. 230, caput da CF, que atribui à família, à sociedade e ao Estado o dever de amparar as pessoas idosas, defendendo sua dignidade e bem-estar e garantindo-lhes o direito à vida. Precedentes: ADI n ${ }^{\circ} 2.163 /$ RJ e ADI no 107-8/AM. Ausência de plausibilidade jurídica na alegação de ofensa ao $\$ 7^{\circ}$ do art. 150 da Constituição Federal, tendo em vista que esse dispositivo estabelece mecanismo de restituição do tributo eventualmente pago a maior, em decorrência da concessão do desconto ao consumidor final. Precedente: $\mathrm{ADI} \mathrm{n}^{\circ}$ 1.851/AL. Matéria relativa à intervenção de Estado-membro no domínio econômico relegada ao exame do mérito da ação. Medida liminar indeferida. Plenário. Relatora: Ministra Ellen Gracie. Brasília, 13 de março de 2002. DJ. 31.10.2003.

${ }^{42}$ BRASIL. Supremo Tribunal Federal. Recurso Extraordinário. $R E$ n. 189.170. Recurso extraordinário. Farmácia. Fixação de horário de funcionamento. Assunto de interesse local. A fixação de horário de funcionamento para o comércio dentro da área municipal pode ser feita por lei local, visando o interesse do consumidor e evitando a dominação do mercado por oligopólio. Precedentes. Recurso extraordinário não conhecido. Segunda Turma. Relator: Ministro Maurício Corrêa. Brasília, 1, de fevereiro de 2001. 


\section{Considerações finais}

Ante tudo quanto foi exposto, podemos chegar a algumas conclusões acerca da aplicação judicial encetada pelo STF na solução das questões que lhe são submetidas e que têm o direito consumidor como parâmetro normativo. Com efeito, o Tribunal tende a não conhecer questões relativas aos direitos do consumidor, sob a justificativa de se tratarem de matéria de caráter infraconstitucional. Superado o óbice do conhecimento, o Tribunal, na maioria dos casos submetidos ao seu crivo, tem uma jurisprudência favorável aos direitos dos consumidores.

Nas questões relativas à competência constitucional, o STF tende a decidir favoravelmente à intervenção normativa dos Estados e dos Municípios nas matérias relativas aos direitos de proteção dos consumidores.

A resposta à principal indagação que todos gostaríamos de ouvir - Os consumidores podem confiar na proteção judicial fornecida pelo STF? - à luz de sua jurisprudência, pelo que vimos, ouso dizer que, lamentavelmente, a Corte não é a principal guardiã dos direitos constitucionais fundamentais dos consumidores, pois refuga a esmagadora maioria dos feitos, sob a alegação de cuidar-se de matéria infraconstitucional. Mas, como assinalei, se superado o óbice do conhecimento, os consumidores podem confiar na proteção constitucional do STF.

\section{Referências}

ALVES JR., Luís Carlos Martins. Direitos constitucionais fundamentais. Belo Horizonte: Mandamentos, 2010.

BRASIL. Supremo Tribunal Federal. Ação Declaratória de Constitucionalidade n. 9. Plenário. Relatora: Ministra Ellen Gracie. Plenário. Brasília, 13 de dezembro de 2001.

BRASIL. Supremo Tribunal Federal. Ação Direta de Inconstitucionalidade n. 2.591. Plenário. Relator: Ministro Eros Grau. Brasília, 7 de junho de 2006.

BRASIL. Supremo Tribunal Federal. Ação Direta de Inconstitucionalidade n. 1.980. Plenário. Relator: Ministro Cezar Peluso. Brasília, 16 abril de 2009.

BRASIL. Supremo Tribunal Federal. Ação Direta de Inconstitucionalidade n. 2.832. Plenário. Relator: Ministro Ricardo Lewandowski. Brasília, 7 de maio de 2008.

BRASIL. Supremo Tribunal Federal. Ação Direta de Inconstitucionalidade n. 855. Plenário. Relator: Ministro Octávio Gallotti. Brasília, 6 de março de 2008.
BRASIL. Supremo Tribunal Federal. Ação Direta de Inconstitucionalidade n. 2.359. Plenário. Relator: Ministro Eros Grau. Brasília, 27, de setembro de 2006.

BRASIL. Supremo Tribunal Federal. Ação Direta de Inconstitucionalidade n. 3.322. Plenário. Relator: Ministro Gilmar Mendes. Brasília, 2, de dezembro de 2010.

BRASIL. Supremo Tribunal Federal. Ação Direta de Inconstitucionalidade n. 3.645. Plenário. Relatora: Ministra Ellen Gracie. Brasília, 31, de maios de 2006.

BRASIL. Supremo Tribunal Federal. Ação Direta de Inconstitucionalidade n. 2.435. Medida Cautelar. Plenário. Relatora: Ministra Ellen Gracie. Brasília, 13 de março de 2002.

BRASIL. Supremo Tribunal Federal. Agravo de Instrumento n. 751.521. Plenário. Relator: Ministro Gilmar Mendes. Brasília, 13 de agosto de 2010.

BRASIL. Supremo Tribunal Federal. Agravo de Instrumento n. 754.745. Plenário. Relator: Ministro Gilmar Mendes. Brasília, 13 de agosto de 2010.

BRASIL. Supremo Tribunal Federal. Agravo de Instrumento n. 762.184. Plenário. Relator Ministro Cezar Peluso. Brasília, 22, de outubro de 2009.

BRASIL. Supremo Tribunal Federal. Agravo de Instrumento n. 762.184. Questão de Ordem. Relator: Ministro Cezar Peluso. Brasília, 22 de outubro de 2009.

BRASIL. Supremo Tribunal Federal. Agravo de Instrumento n. 765.567. Plenário. Relator: Ministro Gilmar Mendes. Brasília, 13 de agosto de 2010.

BRASIL. Supremo Tribunal Federal. Agravo de Instrumento n. 804.209. Plenário. Relator Ministro Gilmar Mendes. Brasília, 16 de setembro de 2010.

BRASIL. Supremo Tribunal Federal. Agravo de Instrumento n. 839.695. Plenário. Relator: Ministro Presidente. Brasília, 9 de junho de 2011.

BRASIL. Supremo Tribunal Federal. Agravo de Instrumento n. 844.474. Plenário. Relator: Ministro Presidente. Brasília, 9 de junho de 2011.

BRASIL. Supremo Tribunal Federal. Agravo de Instrumento n. 844.777. Plenário. Relator: Ministro Presidente. Brasília, 9 de junho de 2011.

BRASIL. Supremo Tribunal Federal. Agravo em Recurso Extraordinário n. 643.085. Plenário. Relator Ministro Presidente. Brasília, 5 de agosto de 2011. . 
BRASIL. Supremo Tribunal Federal. Agravo em Recurso Extraordinário n. 640.713. Plenário. Relator: Ministro Presidente. Brasília, 5 de agosto de 2011.

BRASIL. Supremo Tribunal Federal. Agravo em Recurso Extraordinário n. 640.523. Plenário. Relator: Ministro Presidente. Brasília, 23 de junho de 2011.

BRASIL. Supremo Tribunal Federal. Agravo em Recurso Extraordinário n. 638.484. Plenário. Relator: Ministro Presidente. Brasília, 9 de junho de 2011.

BRASIL. Supremo Tribunal Federal. Agravo em Recurso Extraordinário n. 640.525. Plenário. Relator: Ministro Presidente. Brasília, 9 de junho de 2011.

BRASIL. Supremo Tribunal Federal. Informativo n. 531.

BRASIL. Supremo Tribunal Federal. Recurso Extraordinário n. 189.170. Segunda Turma. Relator: Ministro Maurício Corrêa. Brasília, 1 de fevereiro de 2001.

BRASIL. Supremo Tribunal Federal. Recurso Extraordinário n. 201.630. 1 $1^{\text {a }}$ Turma. Relatora: Ministra Ellen Gracie. Brasília, 11 de junho de 2002.

BRASIL. Supremo Tribunal Federal. Recurso Extraordinário n. 214.349. $1^{\text {a }}$ Turma. Relator: Ministro Moreira Alves. Brasília, 13 de abril de 1999.

BRASIL. Supremo Tribunal Federal. Recurso Extraordinário n. 297.901. 2a Turma. Relatora: Ministra Ellen Gracie. Brasília, 7 março de 2006.

BRASIL. Supremo Tribunal Federal. Recurso Extraordinário n. 351.750. 1 ${ }^{\mathrm{a}}$ Turma. Relator: Ministro Ayres Britto. Brasília, 17 março de 2009.

BRASIL. Supremo Tribunal Federal. Recurso Extraordinário n. 432.789. $1^{\text {a }}$ Turma. Relator: Ministro Eros Grau. Brasília, 14 de junho de 2005.
BRASIL. Supremo Tribunal Federal. Recurso Extraordinário n. 565.138. Plenário. Relator: Ministro Menezes Direito. Brasília, 5, de dezembro de 2007.

BRASIL. Supremo Tribunal Federal. Recurso Extraordinário n. 576.189. Plenário. Relator: Ministro Ricardo Lewandowski. Brasília, 20, de março de 2008.

BRASIL. Supremo Tribunal Federal. Recurso Extraordinário n. 579.073. Plenário. Relator Ministro Cezar Peluso. Brasília, 17 de setembro de 2009.

BRASIL. Supremo Tribunal Federal. Recurso Extraordinário n. 591.797. Plenário. Relator: Ministro Dias Toffoli. Brasília, 15 abril de 2010.

BRASIL. Supremo Tribunal Federal. Recurso Extraordinário n. 611.639. Plenário. Relator: Ministro Marco Aurélio. Brasília, 9 de dezembro de 2010.

BRASIL. Supremo Tribunal Federal. Recurso Extraordinário n. 641.005. Plenário. Relator: Ministro Luiz Fux. Brasília, 24 de maio de 2012.

BRASIL. Supremo Tribunal Federal. Recurso Extraordinário n. 667.958. Repercussão Geral. Relator: Ministro Gilmar Mendes. Plenário. J. 8.3.2012.

BRASIL. Supremo Tribunal Federal. Recurso Extraordinário n. 351.750. Brasília, DF, 2009.

BRITTO, Ayres. Brasil. Supremo Tribunal Federal. Recurso Extraordinário n. 351.750. Brasília, DF, 2009.

GRAU, Eros Roberto. Ensaio e discurso sobre a interpretação/aplicação do direito. 2. ed. São Paulo: Malheiros, 2006. 


\section{Para publicar na revista Universitas/JUS, acesse $o$ endereço eletrônico www.publicacoesacademicas.uniceub.br.}

Observe as normas de publicação, para facilitar e agilizar o trabalho de edição. 